\title{
PENGARUH EFIKASI DIRI, AKTIVITAS, KEMANDIRIAN BELAJAR DAN KEMAMPUAN BERPIKIR LOGIS TERHADAP HASIL BELAJAR MATEMATIKA PADA SISWA KELAS VIII SMP
}

\author{
Sitti Fitriana ${ }^{1}$, Hisyam Ihsan ${ }^{2}$, Suwardi Annas ${ }^{3}$ \\ ${ }^{1}$ Guru Matematika SMP, \\ SMP Negeri Polongbangkeng Utara, Takalar, Sulawesi Selatan \\ email: Sittifitri_a@yahoo.com
}

\begin{abstract}
This study aims to identify and explain how much influence the effect of self-efficacy, activity, independent learning and the ability to think logically to the learning outcomes of mathematics at Junior High School eighth grade students in the District of North Polongbangkeng Takalar. This research is an ex-post facto nature of causality. The population in this study is the Junior High School eighth grade students in the District of North Polongbangkeng KabupatenTakalar the school year 2014/2015. The study population 581 students and 172 students study sample taken using proportional random sampling. The instrument used consisted of self-efficacy questionnaire, questionnaire learning activities, questionnaires independent learning, logical thinking ability test and mathematics achievement test. Data were analyzed with descriptive statistics and inferential statistical analysis (path anlysis). The results showed that (1) Most of the Junior High School eighth grade students in the District of North Polongbangkeng have self-efficacy, learning activities, Learning Independence, ability to think logically and mathematics learning outcomes in the medium category. (2) The variables that significantly namely: self-efficacy directly influence the outcome of learning, independent learning, the ability to think logically. Learning activities directly affect learning independence, and ability to think logically. (3) Variables that influence is not significant, namely: self-efficacy does not directly influence the activity of learning, Self efficacy indirect effect on learning outcomes through independent learning, Self efficacy not significant effect indirectly on learning outcomes through kemamuan think logically, Learning Activities no direct effect on learning outcomes, learning activities indirect effect on learning outcomes through independent learning, learning activities indirect effect on learning outcomes through logical thinking skills, independent learning has no direct effect on learning outcomes, the ability to think logically not directly affect learning outcomes.
\end{abstract}

Keywords: Self Efficacy, Learning Activity, Learning Independence, Logical Thinking Skills, and Learning Outcomes.

\begin{abstract}
ABSTRAK
Penelitian ini bertujuan untuk mengetahui dan menjelaskan seberapa besar pengaruh efikasi diri, aktivitas, kemandirian belajar dan kemampuan berpikir logis terhadap hasil belajar matematika pada siswa kelas VIII SMP Negeri Di Kecamatan Polongbangkeng Utara Kabupaten Takalar. Penelitian ini adalah penelitian ex-post facto yang bersifat kausalitas. Populasi dalam penelitian ini adalah siswa Kelas VIII SMP Negeri di Kecamatan Polongbangkeng Utara Kabupaten Takalar tahun pelajaran 2014/2015 yang berjumlah 581 siswa dan Sampel penelitian 172 siswa yang diambil dengan menggunakan proporsional random sampling. Instrumen yang digunakan terdiri dari angket efikasi diri, angket aktivitas belajar, angket kemandirian belajar, tes kemampuan berpikir logis, dan tes hasil belajar matematika. Data dianalisis dengan statistika deskriptif dan analysis statistika inferensial (path anlysis). Hasil penelitian menunjukkan bahwa (1) Sebagian besar siswa memiliki efikasi diri, aktivitas belajar, Kemandirian
\end{abstract}




\begin{abstract}
Belajar, Kemampuan berpikir logis dan hasil belajar matematika dengan kategori sedang. (2) Variabel yang berpengaruh secara signifikan yaitu: efikasi diri berpengaruh langsung terhadap hasil belajar, kemandirian belajar, kemampuan berpikir logis. Aktivitas belajar berpengaruh langsung terhadap kemandirian belajar, dan kemampuan berpikir logis. (3) Variabel yang berpengaruh secara tidak signifikan yaitu: efikasi diri tidak berpengaruh langsung terhadap aktivitas belajar, Efikasi diri berpengaruh tidak langsung terhadap hasil belajar melalui kemandirian belajar, Efikasi diri berpengaruh tidak signifikan secara tidak langsung terhadap hasil belajar melalui kemamuan berpikir logis, Aktivitas belajar tidak berpengaruh langsung terhadap hasil belajar, Aktivitas belajar berpengaruh tidak langsung terhadap hasil belajar melalui kemandirian belajar, Aktivitas belajar berpengaruh secara tidak langsung terhadap hasil belajar melalui kemampuan berpikir logis, kemandirian belajar tidak berpengaruh langsung terhadap hasil belajar, kemampuan berpikir logis tidak berpengaruh secara langsung terhadap hasil belajar.
\end{abstract}

Kata Kunci: Efikasi Diri, Aktivitas Belajar, Kemandirian Belajar, Kemampuan Berpikir Logis, dan Hasil Belajar.

\section{PENDAHULUAN}

Keberhasilan pendidikan akan dicapai oleh suatu bangsa apabila ada usaha untuk meningkatkan mutu pendidikan bangsa itu sendiri. Untuk menghasilkan output yang berkualitas dalam proses pendidikan sangat dipengaruhi oleh berhasil tidaknya kegiatan belajar. Dengan demikian mutu pendidikan kita harus ditingkatkan agar dapat menghasilkan lulusan yang dapat bersaing dengan Negara lain. Hal tersebut diperlukan karena akan menjadi penopang utama pembangunan nasional yang mandiri dan berkeadilan serta menjadi jalan keluar bagi bangsa Indonesia untuk terlepas dari kemiskinan dan pengangguran. Dalam usaha pengembangan ilmu pengetahuan dan teknologi tersebut, perlu adanya penguasaan matematika.Matematika merupakan suatu mata pelajaran yang diajarkan pada setiap jenjang pendidikan di Indonesia mulai dari sekolah dasar (SD) sampai dengan perguruan tinggi.

Melalui pelajaran matematika, seseorang akan mampu mengetahui mata rantai penalaran dan kaidah-kaidah yang dimiliki dalam pelajaran matematika, selain itu juga mampu membangun model atau instrument dari gejala keilmuan yang telah diamati. Hal ini berarti bahwa melalui pelajaran matematika, seorang siswa diharapkan agar memiliki kemampuan dan keterampilan dalammelakukan penalaran, berfikir kritis, dan logis. Berfikir kritis berarti siswa harus mampu untuk selalu memberikan pertanyaan tentang sesuatu yang dipelajarinya dan selalu mencari akan sesuatu yang ingin diketahuinya serta menunjukkan jawaban yang bersifat logis dengan menggunakan suatu prosedur secara sistematis, sehingga dengan demikian siswa yang sudah mampu menguasai pelajaran matematika secara tuntas diharapkan mampu mentransfer pengetahuan dan konsep dasar matematis dalam memecahkan suatu persoalan bidang studi yang lain melalui kerjasama atau diskusi dengan baik. Namun kenyataannya hasil belajar matematika pada jenjang pendidikan dasar dan menengah di Indonesia secara umum masih relatif rendah jika dibandingkan dengan mata pelajaran lainnya.

Hal ini terlihat dengan adanya hasil survey yang dilakukan oleh Trend Mathematics and Science Study (TIMSS) tahun 2011 melaporkan bahwa penguasaan matematika siswa Indonesia berada diperingkat 38 dari 45 negara yang dievaluasi dengan skor rata-rata yang diperoleh adalah 386 dari nilai yang tertinggi 613 yang diraih oleh Republik Korea. Sementara hasil konferensi pers mendikbud tentang hasi UN SMP tahun 2013, tahun ajaran 2012/2013 provinsi Sulawesi Selatan memiliki presentase ketidaklulusan sebesar $1,18 \%$ (urutan 11 dari 3 provinsi). Dari 134.923 siswa SMP seSulawesi Selatan diantaranya sebanyak 1.596 siswa dinyatakan tidak lulus. Bahkan Sulawesi Selatan menjadi penyumbang terbanyak kedua jumlah siswa SMP tidak lulus setelah NTT sebanyak 1.922 siswa. Hasil UN yang telah diketahui yaitu siswa SMP yang tidak lulus 
mencapai 15.45 siswa, yang terbanyak gagal dalam mata pelajaran matematika, yaitu 1.330 siswa.

Data lain yang diperoleh setelah melakukan observasi pada beberapa sekolah SMP Negeri Di Kecamatan Polongbangkeng Utara Kabupaten Takalar, data hasil belajar matematika siswa semester ganjil tahun ajaran 2014/2015 masih rendah dan memprihatinkan dibandingkan dengan hasil belajar mata pelajaran lainnya. Hal tersebut ditunjukkan oleh rata-rata 69\% siswa kelas VIII belum mencapai KKM. Proses pembelajaran dikatakan tuntas secara klasikal jika 85\% dari jumlah siswa telah mencapai nilai minimal 75 dari evaluasi pembelajaran yang dilakukan

Kita perlu sadari bahwa walaupun berbagai upaya telah dilakukan dalam meningkatkan hasil belajar matematika siswa seperti perbaikan kurikulum, lengkapnya sarana, cakapnya guru mengelola proses pembelajaran, tidak akan berarti bila peserta didik tidak bersungguh-sungguh di dalam kegiatan belajarnya. Kesungguhan peserta didik dalam belajar sangat ditentukan oleh berbagai faktor. Seperti yang dijelaskan Slameto (2010: 56), "belajar adalah suatu proses yang kompleks dengan banyak faktor yang mempengaruhinya." Faktor tersebut adalah faktor internal (faktor yang berasal dari dalam diri siswa) dan faktor eksternal (faktor yang berasal dari luar diri siswa). Faktor internal yang berpengaruh terhadap belajar adalah efikasi diri, aktivitas belajar, kemandirian belajar dan kemampuan berpikir logis.

Efikasi diri akan mempengaruhi beberapa aspek dari kognisi dan perilaku seseorang. Gist dan Mitchell mengatakan bahwa efikasi diri dapat membawa pada perilaku yang berbeda di antara individu dengan kemampuan yang sama karena efikasi diri mempengaruhi pilihan, tujuan, pengatasan masalah, dan kegigihan dalam berusaha. Seseorang dengan efikasi diri tinggi percaya bahwa mereka mampu melakukan sesuatu untukmengubah kejadiankejadian disekitarnya, sedangkan seseorang dengan efikasi diri rendah menganggap dirinya pada dasarnya tidak mampu mengerjakan segala sesuatu yang ada disekitarnya.Dalam setuasi yang sulit, orang dengan efikasi yang rendah cenderung mudah menyerah.Sementara orang dengan efikasi diri yang tinggi akan berusaha lebih keras untuk mengatasi tantangan yang ada. Hal senada juga diungkapkan oleh Gist, yang menunjukkan bukti bahwa perasaan efikasi diri memainkan satu peran penting dalam mengatasi memotivasi pekerja untuk menyelesaikan pekerjaan yang menantang dalam kaitannya dengan pencapaian tujuan tertentu.

Selanjutnya, faktor yang juga perlu diperhatikan adalah aktivitas belajar siswa sebab aktivitas merupakan hal yang menunjang usaha peningkatan hasil belajar. Kegiatan atau kesibukan yang dilakukan seseorang dalam belajar akan mempengaruhi hasil belajarnya. Siswa yang belajar dengan cara menulis, mengerjakan soal-soal, membuat rangkuman hasilnya akan lebih baik dari pada siswa yang belajarnya hanya membaca saja. Aktivitas dapat dilakukan siswa selama disekolah dan dirumah. Aktivitas di sekolah berupa kegiatan yang dilakukan siswa secara jasmani dan rohani yang menunjang proses belajar mengajar misalnya mencatat, mendengarkan penjelasan guru, bertanya pada guru, pergi keperpustakaan dan sebagainya. Sedangkan aktivitas belajar di rumah berupa kegiatan yang dilakukan siswa selama di rumah dan merupakan kelanjutan dari belajar di sekolah misalnya mengerjakan PR, mengerjakan latihan-latihan soal, merapikan catatan, dan sebagainya.Masih banyak dijumpai aktivitas belajar di sekolah didominasi oleh guru sedangkan siswa pasif dan menerima materi pelajaran begitu saja. Aktivitas siswa terbatas pada pendengaran, mencatat, menjawab pertanyaan bila guru memberikan pertanyaan. Memang benar siswa tidak pasif secara mutlak, hanya proses pembelajaran seperti ini jelas tidak mendorong siswa untuk berfikir kreatif dan beraktifitas. Jika aktivitas siswa terhambat maka akan mempengaruhi hasil belajar siswa.

Selanjutnya kemandirian siswa dalam belajar juga merupakan salah satu faktor penting yang harus diperhatikan untuk mencapai hasil belajar yang baik.Kemandirian merupakan salah satu segi dari sifat seseorang. Kemandirian siswa dalam belajar merupakan suatu hal yang sangat penting dan perlu dikembangkan pada siswa sebagai individu yang diposisikan sebagai peserta didik. Dengan ditumbuh kembangkannya kemandirian pada siswa, membuat siswa dapat mengerjakan segala sesuatu sesuai dengan kemampuan yang dimilikinya. Siswa yang memiliki kemandirian belajar yang tinggi akan 
berusaha menyelesaikan latihan atau tugas yang diberikan oleh guru dengan kemampuan yang dimilikinya, sebaliknya siswa yang memiliki kemandirian belajar yang rendah akan tergantung pada orang lain.

Menurut Mudjiman (Assagaf 2014: 5), belajar mandiri dapat diartikan sebagai kegiatan belajar aktif, yang didorong oleh niat untuk menguasai suatu kompetensi guna mengatasi suatu masalah dan dibangun dengan bekal pengetahuan atau kompetensi yang telah dimiliki.

Faktor lain yang mempengaruhi hasil belajar siswa yaitu kemampuan berfikir logis yang dimiliki siswa. Berfikir secara logis adalah suatu proses berfikir secara konsisten untuk mengambil sebuah kesimpulan. Kemampuan berfikir logis ini merupakan kemampuan esensial yang perlu dimiliki dan dikembangkan pada siswa yang belajar matematika karena kemampuan tersebut sesuai dengan tujuan pendidikan nasional dan tujuan pembelajaran matematika sekolah yang menuntut siswa berkembang dan memiliki dasar pemikiran secara logis, rasional, kritis, cermat, jujur, efisien, dan efektif.

Hasil belajar merupakan cerminan dari usaha belajar, semakin baik usaha belajarnya, maka semakin baik pula hasil yang diraihnya. Hasil belajar dapat dijadikan sebagai indikator keberhasilan dalam belajar. Hasil belajar yang baik akan dapat dicapai oleh siswa apabila mereka dapat mengatasi kesulitan belajar yang dialaminya.

Dari uraian diatas dapat dimengerti bahwa mutu pendidikan tidaklah ditentukan oleh fator tunggal, namun ada sejumlah variabel yang dianggap saling mempengaruhi. Hal itulah yang menggugah penulis untuk melakukan suatu kajian sederhana yakni Input-Proses-Output yang mengacu pada sejumlah variabel yaitu: Efikasi diri, Aktivitas Belajar, Kemandirian Belajar, dan kemampuan berfikir logis terhadap hasil belajar matematika.

Berdasarkan latar belakang yang telah dijelaskan di atas, dirumuskan masalah sebagai berikut:

1. Bagaimana gambaran efikasi diri, aktivitas belajar, kemandirian belajar, kemampuan berfikir logis dan hasil belajar matematika siswa kelas VIII SMP Negeri Di Kecamatan Polongbangkeng Utara?
2. Sejauh mana pengaruh efikasi diri terhadap hasil belajar matematika baik secara langsung maupun tidak langsung melalui kemandirian belajar siswa kelas VIII SMP Negeri Di Kecamatan Polongbangkeng Utara?

3. Sejauh mana pengaruh aktivitas belajar terhadap hasil belajar matematika baik secara langsung maupun tidak langsung melalui kemandirian belajar siswa kelas VIII SMP Negeri Di Kecamatan Polongbangkeng Utara?

4. Sejauh mana pengaruh efikasi diri terhadap hasil belajar matematika baik secara langsung maupun tidak langsung melalui kemampuan berpikir logis siswa kelas VIII SMP Negeri Di Kecamatan Polongbangkeng Utara?

5. Sejauh mana pengaruh aktivitas belajar terhadap hasil belajar matematika baik secara langsung maupun tidak langsung melalui kemampuan berpikir logis siswa kelas VIII SMP NegeriDi Kecamatan Polongbangkeng Utara?

Tinjauan pustaka terhadap berbagai variabel yang mempengaruhi hasil belajar seperti efikasi diri, aktivitas belajar, kemandirian belajar, dan kemampuan berpikir logis, menunjukkan bahwa:

(1) Efikasi diri Menurut Bandura (Hidayat 2011: 156), semua pemikiran yang mempengaruhi fungsi manusia dan merupakan bagian paling inti dari teori kognitif sosial adalah efikasi diri (self efficacy). Efikasi diri adalah penilaian diri terhadap kemampuan diri untuk mengatur dan melaksanakan tindakan yang diperlukan untuk mencapai kinerja yang ditetapkan.Menurut Ormod (2009: 20), efikasi diri adalah penilaian seseorang tentang kemampuannya sendiri untuk menjalankan perilaku tertentu atau mencapai tujuan tertentu.Menurut (Ghufron \& Risnawita, 2010), efikasi diri merupakan salah satu aspek pengetahuan tentang diri atau self-knowledge yang paling berpengaruh dalam kehidupan manusia sehari-hari. Hal ini disebabkan efikasi diri yang dimiliki ikut mempengaruhi individu dalam menentukan tindakan yang akan dilakukan untuk mencapai suatu tujuan, termasuk didalamnya perkiraan berbagai kejadian yang akan dihadapi. Menurut Bandura (Ghufron \& Risnawita, 2010), efikasi diri adalah keyakinan individu 
mengenai kemampuan dirinya dalam melakukan tugas atau tindakan yang diperlukan untuk mencapai hasil tertentu. Sementara itu, Baron \& Byrne (Ghufron \& Risnawita, 2010), mendefenisikan efikasi diri sebagai evaluasi seseorang mengenai kemampuan atau kompetensi dirinya untuk melakukan suatu tugas, mencapai tujuan, dan mengatasi hambatan. Menurut Bandura (Ernawati 2013: 16), efikasi diri merupakan suatu keyakinan seseorang atas kemampuannya untuk melaksanakan tugas khusus atau bagian dari berbagai komponen tugas. Efikasi diri adalah suatu keyakinan dalam kemampuan seseorang untuk mengorganisir dan melakukan serangkaian tindakan yang dibutuhkan untuk mengatur situasi yang akan datang. Secara Kontekstual, Bandura memberikan definisi bahwa efikasi diri adalah keyakinan seseorang mengenai kemampuan yang dimilikinya untuk menghasilkan tingkatan performayang terencana, dimana kemampuan tersebut dilatih, digerakkan oleh kejadian-kejadian yang berpengaruh dalam hidup seseorang

Berdasarkan pendapat diatas dapat disimpulkan bahwa inti dari efikasi diri adalah keyakinan atas kemampuan diri. Efikasi diri merupakan keyakinan seseorang untuk mengkoordinir kemampuan dirinya sendiri yang dimanifestasikan dengan serangkaian tindakan dalam memenuhi tuntutan-tuntutan dalam hidupnya.

(2) Aktivitas belajar bukanlah berproses dalam kehampaan. Tidak pula pernah sepi dari berbagai aktivitas. Tidak pernah terlihat orang yang belajar tanpa melibatkan aktivitas raganya. Apalagi bila aktivitas belajar itu berhubungan dengan masalah belajar menulis, mencatat, memandang, membaca, mengingat, berpikir, latihan atau praktek dan sebagainya. Dalam belajar seseorang tidak akan dapat menghindarkan diri dari suatu situasi. Situasi akan menentukan aktivitas apa yang akan dilakukan dalam rangka belajar. Bahkan situasi itulah yang mempengaruhi dan menetukan aktivitas belajar apa yang dilakukan kemudian. Setiap setuasi di manapun dan kapanpun memberikan kesempatan belajar kepada seseorang.
Sekolah merupakan pusat belajar yang berfungsi sebagai tempat untuk mengembangkan aktivitas. Aktivitas belajar dalam proses pembelajaran sangat menentukan hasil belajar siswa, terutama aktivitas siswa selama mengikuti proses belajar mengajar. Aktivitas belajar siswa adalah serangkaian kegiatan siswa baik fisik maupun mental yang saling berkaitan selama proses pembelajaran sehingga tercipta pembelajaran yang optimal (Sardiman, 2012: 100; Muslimin 2014: 33). Aktivitas siswa selama proses belajar mengajar merupakan salah satu indikator adanya keinginan siswa untuk belajar.

Aktivitas sangat diperlukan dalam belajar, karena pada prinsipnya belajar adalah berbuat untuk mengubah tingkah laku. Pernyataan ini menunjukan bahwa setiap orang yang belajar harus aktif sendiri, tanpa aktivitas proses belajar tidak mungkin terjadi. Siswa akan lebih mudah mempelajari sesuatu bila belajar itu disadari pada apa yang telah dipelajari sebelumnya.

Berdasarkan pengertian tersebut dapat disimpulkan aktivitas belajar adalah kegiatan pengamatan, penyeledikan, pengalaman yang dimiliki dan dilakukan sendiri oleh siswa yang bertujuan untuk memperoleh pengetahuan.

(3) Kemandirian Belajar Menurut Knowles (Nurhayati, 2011: 137), ada beberapa istilah untuk menunjukkan kemandirian belajar, antara lain: "independent learning, self directed learning, autonomous learning, self instruction, self accses, self study, self education, out-of-class learning, selfplanned learning". Dari beberapa istilah tersebut, independent learning dan self directed learning, yaitu suatu proses di mana individu mengambil inisiatif dengan atau bantuan orang lain dalam mendiagnosis kebutuhan belajar, mengidentifikasi sumber belajar, merumuskan tujuan belajar, mengidentifikasi sumber belajar, memiliki dan mengimplemetasikan stategi belajar, dan mengevaluasi hasil belajar.

$$
\text { Menurut Mujiamn (Nurhayati }
$$

(2011: 141), kemandirian Belajar adalah kegiatan belajar aktif yang didorong oleh niat atau motif untuk menguasai suatu masalah, dibangun dengan bekal 
pengetahuan atau kompetensi yang dimiliki, baik dalam menetapkan waktu belajar, tempat belajar, irama belajar, tempo belajar, cara belajar, maupun evaluasi belajar yang dilakukan oleh pembelajaran sendiri". Dalam pengertian ini, kemnadirian belajar sebagai usaha pembelajaran untuk melakukan kegiatan belajar yang didasari oleh niatnya untuk menguasai suatu kompetensi tertentu.

Menurut Moore dan keegan (Nurhayati 2011: 142 ), kemandirian belajar apat dilihat dalam hal: (1) menentukan tujuan belajar, (2) menentukan cara belajar, (3) evaluasi hasil belajar. Menurut Moore, pembelajaran yang memiliki kemandirian dalam menentukan tujuan dan cara belajar menjadi ciri penting yang membedakan dengan pembelajar yang tidak mandiri. Karena perbedaan ini pulalah hasil belajar yang diperoleh dapat dievaluasi sendiri untuk bahan pembelajaran lebih lanjut.

Dari beberapa pendapat para ahli di atas, dapat disimpulkan bahwa dalam pendidikan yang menekankan kemandirian belajar dapat dilihat dari seberapa besar pembelajaran diberikan kemandirian, baik secara individu atau kelompok dalam menentukan: (1) apa yang ingin dicapai; (2) apa saja yang ingin dipelajari dan dari mana sumber belajarnya;(3) bagaimana mencapainya; serta kapan dan bagaimana keberhasilan belajarnya diukur.

(4) Kemampuan Berpikir Logis Menurut Mukhayat (Wahyuddin, 2013: 20), kata logis mengandung makna benar atau tepat berdasarkan aturan-aturan berpikir dan kaidah-kaidah atau patokan-patokan yang umum untuk dapat berpikir tepat. Sedangkan Kant (Tafsir, 2004: 35), membedakan antara rasional dan logis, dimana rasional adalah suatu pemikiran yang masuk akal, yang diukur dengan hukum alam, sedangkan logis adalah suatu pemikiran yang masuk akal yang kebenarannya mengandalkan argumen dan tidak diukur dengan hukum alam. Hal ini berarti dalam kata logis tersebut termuat suatu aturan tertentu yang harus dipenuhi sehingga membuahkan hasil yang benar. Orang berpikir logis akan taat pada aturan logika.
Dalam logika dibutuhkan aturanaturan atau patokan-patokanyang harus diperhatikan untuk dapat berpikir dengan tepat, teliti, dan teratur sehingga diperoleh suatu kebenaran. Dengan demikian berpikir logis dapat diartikan sebagai suatu kegiatan berpikir untuk memperoleh suatu pengetahuan menurut suatu pola tertentu atau logika tertentu.

Selanjutnya,

Saragih

(Kusumaningrum \& Aziz, 2012: 4), mengungkapkan bahwa berpikir logis mempunyai perbedaan dengan menghafal. Menghafal hanya mengacu pada pencapaian kemampuan ingatan belaka. Sedangkan berpikir logis lebih mengacu pada pemahaman pengertian (dapat mengerti), kemampuan aplikasi, kemampuan analisis, kemampuan sintesis, bahkan kemampuan evaluasi untuk membentuk kecakapan.

Memperhatikan makna berpikir logis, menurut Albrecht 1992 (Wahyuddin, 2013: 20), agar seseorang sampai pada berpikir logis harus memahami dalil logika yang merupakan peta verbal yang terdiri dari tiga bagian yang menunjukkan gagasan progresif yaitu: (a) dasar pemikiran atau realitas tempat berpijak, (b) argumentasi atau cara menempatkan dasar pemikiran bersama, dan (c) simpulan atau hasil yang dicapai dengan menerapkan argumentasi pada dasar pemikiran. Dalam matematika proses untuk memperoleh kebenaran secara rasional atau proses menarik kesimpulan dapat dilakukan dengan cara berpikir induktif dan deduktif.

Berikut ini adalah hipotesis yang digunakan dalam penelitian ini, adalah sebagai berikut:

1. Efikasi diri berpengaruh positif terhadap hasil belajar matematika siswa.

2. Efikasi diri berpengaruh positif terhadap hasil belajar matematika siswa melalui kemandirian belajar.

3. Efikasi diri berpengaruh positif terhadap hasil belajar matematika siswa melalui kemampuan berpikir logis.

4. Aktivitas Belajar berpengaruh positif terhadap hasil belajar matematika siswa.

5. Aktivitas berpengaruh positif terhadap hasil belajar matematika siswa melalui kemandirian belajar. 
6. Aktivitas berpengaruh positif terhadap hasil belajar matematika siswa melalui kemampuan berpikir logis.
Adapun diagram keterkaitan pengaruh antara variabel dalam rangka perumusan hipotesis di atas adalah sebagai berikut:

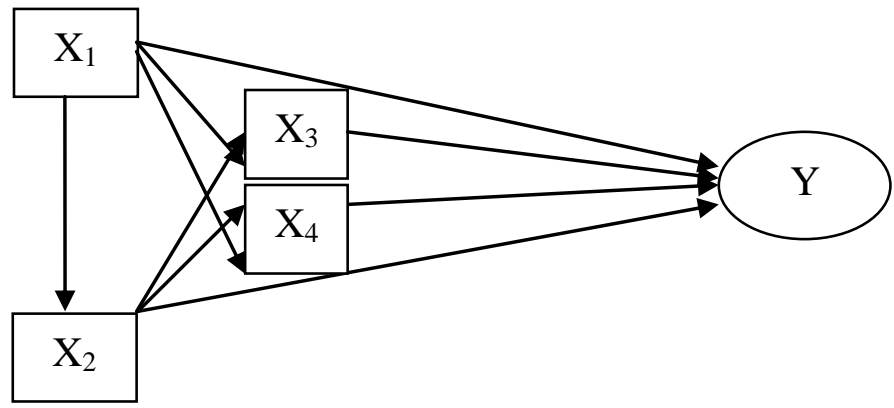

\section{Gambar 2.1 Diagram Hipotik}

Keterangan: $\rightarrow$ : Hubungan Kausal, $\mathrm{X}_{1}$ :Efikasi diri, $\mathrm{X}_{2}$ :Aktivitas belaar,

$\mathrm{X}_{3} \quad$ : Kemandirian belajar, $\mathrm{X}_{4} \quad$ : Kemampuan berpikir logis, $\mathrm{Y}$ : Hasil belajar matematika

\section{METODE PENELITIAN}

Penelitian ini termasuk penelitian ex-post facto yang bersifat kausalitas. Penelitian ex-post facto disini dirancang untuk menerangkan adanya hubungan sebab akibat. Penelitian dalam hal ini akan menelusuri hubungan sebab akibat (kausal) dan menguji hipotesis yang telah dirumuskan sebelumnya antara: efikasi diri, aktivitas belajar, kemandirian belajar dan kemampuan berpikir logis terhadap hasil belajar matematika.

Variabel yang diselidiki dalam penelitian ini terbagi dalam tiga jenis, yaitu variabel eksogen, variabel intervening dan variabel endogen. Variabel eksogen adalah variabel independen yang mempengaruhi variabel dependen. Dalam penelitian ini yang bertindak sebagai variabel eksogen adalah efikasi diri $\left(\mathrm{X}_{1}\right)$ dan aktivitas belajar $\left(X_{2}\right)$. Variabel endogen adalah variabel dependen yang dipengaruhi oleh variabel independen (eksogen) dan dalam penelitian ini yang bertindak sebagai variabel endogen adalah hasil belajar matematika (Y). Variabel intervening adalah variabel yang bertindak sebagai variabel eksogen sekaligus variabel endogen dan merupakan variabel yang menjembatani antara variabel eksogen dengan variabel endogen. Dalam penelitian ini yang bertindak sebagai variabel intervening adalah kemandirian belajar $\left(\mathrm{X}_{3}\right)$ dan kemampuan berpikir logis $\left(\mathrm{X}_{4}\right)$.
Populasi dalam penelitian ini adalah seluruh siswa kelas VIII SMP Negeri di Kecamatan Polongbangkeng Utara Kabupaten Takalar Tahun ajaran 2014/2015. Berdasarkan data yang diperoleh dari Dinas Pendidikan Kabupaten Takalar, diperoleh jumlah SMP Negeri yang ada di Kecamatan Polongbangkeng Utara Kabupaten Takalar sebanyak 4 sekolah dengan jumlah keseluruhan siswa dari sekolah tersebut khususnya kelas VIII adalah 581 siswa.

Sampel adalah sejumlah anggota yang dipilih atau diambil dari suatu populasi. Metode pengambilan sampel yang digunakan untuk memperoleh sampel acak adalah menggunakan teknik proportionalrandom sampling. Sampel pada penelitian ini diambil dari setiap sekolah yang ada di kecamatan Polongbangkeng Utara. Arikunto (2006) mengemukakan bahwa apabila subjek kurang dari 100, maka lebih baik diambil semua, sehingga penelitiannya merupakan penelitian populasi. Selanjutnya, jika subjeknya besar, dapat diambil $15 \%$ atau $25 \%$ atau lebih. Untuk mendapatkan sampel yang proporsional maka pengambilan sampel di ambil $30 \%$ dari setiap sekolah yang ada.

Dari jumlah populasi yang diambil sebagai sampel penelitian sebanyak 581, yang terdiri dari SMPN 1 Polut 286 siswa, SMPN 2 Polut 161 siswa, SMPN 3 Polut 72 siswa dan SMPN 5 Polut 62 siswa. Banyaknya siswa yang menjadi subjek penelitian ini adalah 172 siswa. Selanjutnya, masing-masing sampel untuk setiap 
sekolah diproporsionalkan sesuai dengan jumlah kelas yang ada dalam sekolah tersebut, maka jumlah sampel untuk SMPN 1 Polut 86 siswa, SMPN 2 Polut 47 siswa, SMPN 3 Polut 21 siswa dan SMPN 5 Polut 18 siswa

Peneliti menggunakan instrument yang diberikan kepada setiap sampel penelitian untuk memperoleh data yang diperlukan dari setiap variabel. Adapun instrumen penelitian yang dipergunakan dalam penelitian ini adalah angket dan tes. Angket digunakan untuk mengumpulkan data mengenai variable efikasi diri, aktivitas belajar dan kemandirian belajar. Pada penelitian ini akan digunakan Skala Likert dengan memodifikasi menghilangkan jawaban tengah atau dengan jawaban skala Likert 5-titik.

Skala Likert 5-titik diambil sebagai patokan pada semua butir pernyataan dalam skala penilaian. Oleh karena itu, dalam Skala Likert 5-titik, alasan responden akan diberikan pernyataan dengan pilihan penilaian diri responden antara interval 1 samapai 5. Angka 1 sampai 5 ini merupakan skor nilai dari penilaian responden yang memiliki arti. Skala efikasi diri, skala aktivitas belajar dan skala kemandirian belajar pernyataan positif skor 5 bila responden menjawab sangat sesuai (SS), skor 4 bila responden menjawab sesuai (S), skor 3 bila responden menjawab netral (N) skor 2 bila responden menjawab tidak sesuai (TS), dan skor 1 bila responden menjawab sangat tidak sesuai (STS). Pernyataan negatif skor 1 bila responden menjawab sangat sesuai (SS), skor 2 bila responden menjawab sesuai (S), skor 3 jika responden menjawab Netral $(\mathrm{N})$, skor 4 jika responden menjawab tidak sesuai (TS) dan skor 5 jika responden menjawab sangat tidak sesuai (STS).

Variabel-variabel (efikasi diri, aktivitas belajar dan kemandirian belajar) dikategorikan berdasarkan lima kategori skor yang dikembangkan dalam skala likert dan digunakan dalam penelitian ini. Adapun kriteria yang dimaksud adalah sebagai berikut.

Tabel 1 Kriteria analisis deskriptif

\begin{tabular}{cl}
\hline Rentang Kategori Skor & Penafsiran \\
\hline $\boldsymbol{X} \geq \boldsymbol{M}_{\boldsymbol{i}}+\mathbf{1}, \mathbf{5} \boldsymbol{S} \boldsymbol{D}_{\boldsymbol{i}}$ & Sangat baik/Sangat tinggi \\
$\boldsymbol{M}_{\boldsymbol{i}}+\mathbf{0}, \mathbf{5} \boldsymbol{S} \boldsymbol{D}_{\boldsymbol{i}}<X \leq \boldsymbol{M}_{\boldsymbol{i}}+\mathbf{1}, \mathbf{5} \boldsymbol{S \boldsymbol { D } _ { \boldsymbol { i } }}$ & Baik/Timggi \\
$\boldsymbol{M}_{\boldsymbol{i}}-\mathbf{0}, \mathbf{5} \boldsymbol{S} \boldsymbol{D}_{\boldsymbol{i}}<X \leq \boldsymbol{M}_{\boldsymbol{i}}+\mathbf{0}, \mathbf{5} \boldsymbol{S \boldsymbol { D } _ { \boldsymbol { i } }}$ & Cukup/Sedang \\
$\boldsymbol{M}_{\boldsymbol{i}}-\mathbf{0}, \mathbf{5} \boldsymbol{S} \boldsymbol{D}_{\boldsymbol{i}}<X \leq \boldsymbol{M}_{\boldsymbol{i}}-\mathbf{0}, \mathbf{5 S} \boldsymbol{D}_{\boldsymbol{i}}$ & Tidak baik/Rendah \\
$\boldsymbol{X}<\boldsymbol{M}_{\boldsymbol{i}}-\mathbf{1}, \mathbf{5 S} \boldsymbol{D}_{\boldsymbol{i}}$ & Sangat tidak baik/Sangat rendah \\
\hline
\end{tabular}

Sumber: Nurkancana (1992)

Dimana, $\mathrm{M}_{\mathrm{i}}$ : rata-rata ideal

$\mathrm{SD}_{\mathrm{i}}$ : standar deviasi ideal

Adapun langkah-langkah yang ditempuh untuk melakukan pengumpulan data dalam kegiatan penelitian ini adalah:

1. Melakukan eksplorasi kepustakaan yang mendukung variabel sebagai indikator pengumpul informasi.

2. Melakukan pensahihan (validasi instrumen) terhadap hasil eksplorasi kepustakaan yang dilakukan, sesuai dengan teknik validasi yang digunakan.

3. Melakukan ujicoba pada instrumen penelitian untuk mengukur validitas dan reliabilitas

4. Melakukan pengumpulan data berdasarkan instrumen yang telah diperoleh, diterapkan

pada sampel yang dipilih dalam kegiatan penelitian ini

5. Melakukan analisis pada data yang diperoleh

Menganalisis data hasil penelitian menggunakan teknik statistika deskriptif dan infrensial. Statistika deskriptif dimaksudkan untuk memberikan gambaran alami data sampel dari variabel penelitian, yaitu berupa mean, median, modus, standar deviasi, variansi, skewness, kurtosis, range, minimum, maksimum, dan analisis persentase. Data dianalisis dengan statistika desktiptif dan analisis statistika inferensial dengan menggunakan paket program 
AMOS (Analysis of Moment Structure) SPSS versi 20 dan tes sobel online.

\section{HASIL DAN PEMBAHASAN}

Karakteristik distribusi skor responden masingmasing variabel

a. Variabel Efikasi Diri

\section{Hasil}

Tabel 2 Distribusi Skor Efikasi Diri

\begin{tabular}{lcrrc}
\hline No & Skor & Frekuensi & $\begin{array}{r}\text { Persentasi } \\
(\%)\end{array}$ & Kategori \\
\hline 1 & $60<$ ED & 30 & 17,44 & Sangat Tinggi \\
2 & $47<$ ED $\leq 60$ & 130 & 75,58 & Tinggi \\
3 & $33<$ ED $\leq 47$ & 12 & 6,98 & Sedang \\
4 & $20<$ ED $\leq 33$ & 0 & 0 & Rendah \\
5 & ED $\leq 20$ & 0 & 0 & Sangat Rendah \\
\hline
\end{tabular}

Tabel 3 Statistik Deskriptif Frekuensi Efikasi Diri

\begin{tabular}{c|c}
\hline \multicolumn{2}{c}{ Statistik Efikasi Diri } \\
\hline Mean & 55,23 \\
\hline Std. Deviasi & 5,92 \\
\hline Variansi & 35,09 \\
\hline Minimum & 39 \\
\hline Maksimum & 73 \\
\hline
\end{tabular}

b. Variabel Aktivitas Belajar

Tabel 4 Distribusi Skor Aktivitas Belajar (AB)

\begin{tabular}{lcrrc}
\hline No & Skor & Frekuensi & Persentasi $(\%)$ & Kategori \\
\hline 1 & $86<\mathrm{AB}$ & 119 & 69,19 & Sangat Tinggi \\
2 & $67<\mathrm{AB} \leq 86$ & 60 & 29,07 & Tinggi \\
3 & $48<\mathrm{AB} \leq 67$ & 3 & 1,74 & Sedang \\
4 & $29<\mathrm{AB} \leq 48$ & 0 & 0 & Rendah \\
5 & $\mathrm{AB} \leq 29$ & 0 & 0 & Sangat Rendah \\
\hline Jumlah & & 172 & 100 & \\
\hline Mean & Std.deviasi & Variansi & Minimum & Maksimum \\
\hline 90,63 & 9,80 & 96,07 & 62 & 111 \\
\hline
\end{tabular}

Tabel 5 Statistik Deskriptif Frekuensi Aktivitas Belajar

\begin{tabular}{c|c}
\hline \multicolumn{2}{c}{ Statistik Aktivitas Belajar } \\
\hline Mean & 90,63 \\
\hline Std. Deviasi & 9,80 \\
\hline Variansi & 96,07 \\
\hline Minimum & 62 \\
\hline Maksimum & 111 \\
\hline
\end{tabular}


c. Variabel kemandirian belajar

Tabel 6 Distribusi Skor Kemandirian Belajar (KB)

\begin{tabular}{lcrrc}
\hline No & Skor & Frekuensi & Persentasi $(\%)$ & Kategori \\
\hline 1 & $105<\mathrm{KB}$ & 110 & 63,95 & Sangat Tinggi \\
2 & $82<\mathrm{KB} \leq 105$ & 60 & 34,88 & Tinggi \\
3 & $58<\mathrm{KB} \leq 82$ & 2 & 1,16 & Sedang \\
4 & $35<\mathrm{KB} \leq 58$ & 0 & 0 & Rendah \\
5 & $\mathrm{~KB} \leq 35$ & 0 & 0 & Sangat Rendah \\
\hline
\end{tabular}

Tabel 7 Statistik Deskriptif Frekuensi Kemandirian Belajar

\begin{tabular}{c|c}
\hline \multicolumn{2}{c}{ Statistik Kemandirian Belajar } \\
\hline Mean & 108,71 \\
\hline Std. Deviasi & 11,19 \\
\hline Variansi & 125,16 \\
\hline Minimum & 80 \\
\hline Maksimum & 131 \\
\hline
\end{tabular}

d. Variabel kemampuan berpikir di Logis

Tabel 8 Distribusi Skor Kemampuan Berpikir Logis (BL)

\begin{tabular}{lrrrc}
\hline No & \multicolumn{1}{c}{ Skor } & Frekuensi & Persentasi $(\%)$ & Kategori \\
\hline 1 & $90 \leq \mathrm{BL}<100$ & 14 & 8,14 & Sangat Tinggi \\
2 & $80 \leq \mathrm{BL}<89$ & 35 & 20,35 & Tinggi \\
3 & $65 \leq \mathrm{BL}<79$ & 42 & 24,42 & Sedang \\
4 & $55 \leq \mathrm{BL}<64$ & 60 & 34,88 & Rendah \\
5 & $0 \leq \mathrm{BL} \leq 54$ & 21 & 12,21 & Sangat Rendah \\
\hline
\end{tabular}

Tabel 9 Statistik Deskriptif Skor Kemampuan Berpikir Logis

\begin{tabular}{c|c}
\hline \multicolumn{2}{c}{ Statistik Kemampuan Berpikir Logis } \\
\hline Mean & 67,76 \\
\hline Std. Deviasi & 14,53 \\
\hline Variansi & 211,02 \\
\hline Minimum & 27,27 \\
\hline Maksimum & 100 \\
\hline
\end{tabular}

e. Variabel hasil belajar

Tabel 10 Distribusi Skor Hasil Belajar Matematika (HB)

\begin{tabular}{lrrrc}
\hline No & \multicolumn{1}{c}{ Skor } & Frekuensi & Persentasi $(\%)$ & Kategori \\
\hline 1 & $90 \leq \mathrm{HB}<100$ & 4 & 2,33 & Sangat Tinggi \\
2 & $80 \leq \mathrm{HB}<89$ & 6 & 3,49 & Tinggi \\
3 & $65 \leq \mathrm{HB}<79$ & 77 & 44,77 & Sedang \\
4 & $55 \leq \mathrm{HB}<64$ & 46 & 26,74 & Rendah \\
5 & $0 \leq \mathrm{HB} \leq 54$ & 39 & 22,67 & Sangat Rendah \\
\hline
\end{tabular}


Tabel 11 Statistik Deskriptif Skor Hasil Belajar Matematika

\begin{tabular}{c|c}
\hline \multicolumn{2}{c}{ Statistik Hasil Belajar } \\
\hline Mean & 65,79 \\
\hline Std. Deviasi & 10,27 \\
\hline Variansi & 105,27 \\
\hline Minimum & 46,15 \\
\hline Maksimum & 92,31 \\
\hline
\end{tabular}

Hasil dari analisis jalur dengan Amos for Windows sebagai berikut:

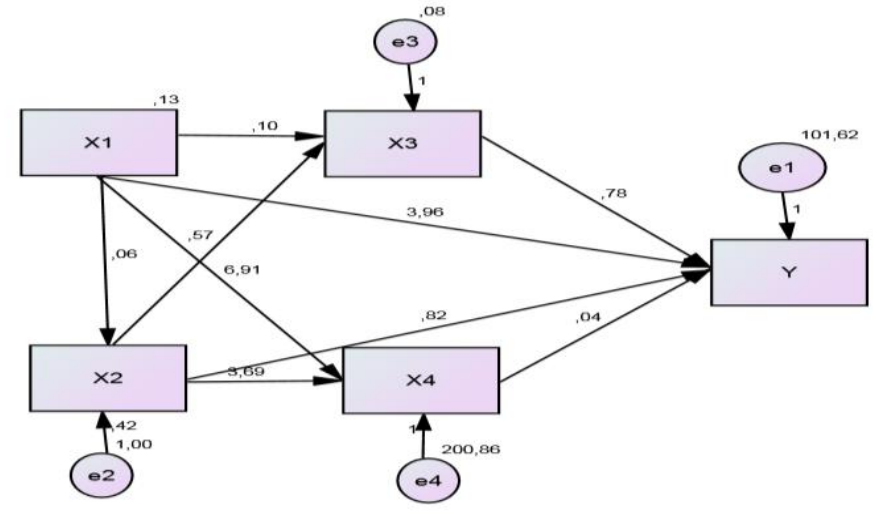

Gambar 4.1. Diagram Hasil Analisis Jalur Amos

Tabel 12 Regression Weights

\begin{tabular}{|c|c|c|c|c|c|c|}
\hline & & & Estimate & S.E. & C.R. & $p$ \\
\hline $\mathrm{X} 2$ & $<--$ & $\mathrm{X} 1$ & 0,06 & 0,09 & 0,65 & 0,520 \\
\hline X3 & $<--$ & X1 & 0,10 & 0,06 & 1,61 & 0,110 \\
\hline X4 & $<--$ & $\mathrm{X} 2$ & 3,69 & 2,57 & 1,44 & 0,150 \\
\hline X4 & $<--$ & X1 & 6,91 & 3,03 & 2,28 & 0,020 \\
\hline X3 & $<--$ & $\mathrm{X} 2$ & 0,57 & 0,05 & 11,26 & $<0,001$ \\
\hline $\mathbf{Y}$ & $<--$ & X3 & 0,78 & 2,76 & 0,28 & 0,780 \\
\hline Y & $<--$ & X4 & 0,04 & 0,05 & 0,70 & 0,480 \\
\hline $\mathbf{Y}$ & $<--$ & X1 & 3,96 & 2,21 & 1,79 & 0,070 \\
\hline Y & $<---$ & $\mathrm{X} 2$ & 0,82 & 2,42 & 0,34 & 0,740 \\
\hline
\end{tabular}

Tabel 13 Standardized Regression Weights

\begin{tabular}{cccc}
\hline & & & Estimate \\
\hline X2 & $<---$ & X1 & 0,05 \\
X3 & $<---$ & X1 & 0,09 \\
X4 & $<---$ & X2 & 0,11 \\
X4 & $<---$ & X1 & 0,17 \\
X3 & $<---$ & X2 & 0,65 \\
Y & $<---$ & X3 & 0,03 \\
Y & $<---$ & X4 & 0,05 \\
Y & $<---$ & X1 & 0,14 \\
Y & $<---$ & X2 & 0,03 \\
\hline
\end{tabular}


Koefisien jalur yang tertera pada Gambar 4.1 bukanlah yang terbakukan (unstandardized) sehingga untuk membandingkan antara koefisien yang satu dengan yang lainnya digunakan koefisien terbakukan (stadardized coefficient)

1. Persamaan Struktur 1: $X_{3}$

$$
\begin{aligned}
& =\mathrm{P}_{31} \mathrm{X}_{1}+\mathrm{P}_{32} \mathrm{X}_{2}+\mathrm{e} 3 \\
& =0,09 \mathrm{X}_{1}+0,65 \mathrm{X}_{2}+1,00
\end{aligned}
$$

2. Persamaan Struktur $2: X_{4}$

$$
\begin{aligned}
& =\mathrm{P}_{41} \mathrm{X}_{1}+\mathrm{P}_{42} \mathrm{X}_{2}+\mathrm{e} 4 \\
& =0,17 \mathrm{X}_{1}+0,11 \mathrm{X}_{2}+1,00
\end{aligned}
$$

Untuk melihat seberapa besar pengaruh langsung, pengaruh tidak langsung dan pengaruh
(Tiro, Sukarna \& Aswi, 2010:63). Berdasarkan koefisien jalur terbakukan yang dapat dilihat pada (standardized regression), maka dapat dibuat persamaan struktur sebagai berikut:

\section{Persamaan Struktur 2: $Y$

$$
\begin{aligned}
= & \mathrm{P}_{\mathrm{Y} 1} \mathrm{X}_{1}+\mathrm{P}_{\mathrm{Y} 2} \mathrm{X}_{2}+\mathrm{P}_{\mathrm{Y} 3} \mathrm{X}_{3}+\mathrm{P}_{\mathrm{Y} 4} \mathrm{X}_{4}+\mathrm{e} 1 \\
= & 0,14 \mathrm{X}_{1}+0,03 \mathrm{X}_{2}+0,03 \mathrm{X}_{3}+0,05 \mathrm{X}_{4}+ \\
& 1,00
\end{aligned}
$$

total dapat dilihat pada Tabel 14 yang merupakan Tabel Dekomposisi Kausalitas Koefisien Jalur.

Tabel 14 Dekomposisi dari Koefisien Jalur

\begin{tabular}{llllcccc}
\hline NO & & \multicolumn{2}{c}{$\begin{array}{c}\text { Pengaruh } \\
\text { Peubah }\end{array}$} & L & $\begin{array}{c}\text { TL } \\
\left(\mathrm{X}_{3}\right)\end{array}$ & $\begin{array}{c}\text { TL } \\
\left(\mathrm{X}_{4}\right)\end{array}$ & Total \\
\hline 1 & \multicolumn{1}{c}{$\mathrm{X}_{1}$} & $\mathrm{Ke}$ & $\mathrm{X}_{2}$ & 0,05 & - & - & 0,05 \\
2 & $\mathrm{X}_{1}$ & $\mathrm{Ke}$ & $\mathrm{X}_{3}$ & 0,09 & - & - & 0,09 \\
3 & $\mathrm{X}_{1}$ & $\mathrm{Ke}$ & $\mathrm{X}_{4}$ & 0,17 & - & - & 0,17 \\
4 & $\mathrm{X}_{1}$ & $\mathrm{Ke}$ & $\mathrm{Y}$ & 0,14 & 0,003 & 0,009 & 0,15 \\
5 & $\mathrm{X}_{2}$ & $\mathrm{Ke}$ & $\mathrm{X}_{3}$ & 0,65 & - & - & 0,65 \\
6 & $\mathrm{X}_{2}$ & $\mathrm{Ke}$ & $\mathrm{X}_{4}$ & 0,11 & - & - & 0,11 \\
7 & $\mathrm{X}_{2}$ & $\mathrm{Ke}$ & $\mathrm{Y}$ & 0,03 & 0,018 & 0,006 & 0,06 \\
8 & $\mathrm{X}_{3}$ & $\mathrm{Ke}$ & $\mathrm{Y}$ & 0,03 & - & - & 0,03 \\
9 & $\mathrm{X}_{4}$ & $\mathrm{Ke}$ & $\mathrm{Y}$ & 0,05 & - & - & 0,05 \\
\hline
\end{tabular}

\section{Pembahasan}

1. Efikasi diri berpengaruh positif terhadap hasil belajar matematika siswa baik secara langsung maupun tidak langsung (melalui kemandirian belajar).

Terkait pengaruh langsung efikasi diri terhadap hasil belajar matematika, hasil penelitian ini didukung oleh hasil penelitian Ilhamsyah (2012) bahwa semakin tinggi efikasi diri ada kecenderungan untuk semakin meningkatkan prestasi belajar matematika siswa. Para siswa menganggap matematika sebagai pelajaran yang sulit untuk dipahami sehingga mereka tidak termotivasi untuk belajar. Siswa yang memiliki efikasi diri yang tinggi mempunyai performansi matematika yang lebih baik dibandingkan dengan siswa yang efikasi dirinya rendah.

Hal tersebut telah dijelaskan oleh Bandura (1997) yang mengungkapkan bahwa individu yang menganggap dirinya tidak mampu menyelesaikan tugas akan berhenti dalam waktu singkat karena ia merasa tidak menguasai kemampuan yang dibutuhkan untuk menyelesaikan tugas tersebut. Sebaliknya, individu yang efikasi dirinya tinggi akan beranggapan bahwa dirinya mampu mengerjakan tugas tersebut, ia merasa memiliki kemampuan yang dibutuhkan untuk menyelesaikan tugas tersebut. Semakin sulit suatu tugas, maka akan semakin tinggi keinginan untuk tekun dalam mengembangkan diri. Efikasi diri meningkatkan kesungguhan individu dalam melaksanakan suatu tugas. Efikasi diri juga dapat menambah 
kemampuan dan meningkatkan daya tahan individu dalam menghadapi berbagai kesulitan yang terus menerus dalam waktu lama.

Berdasarkan hasil pengujian, dapat diketahui bahwa efikasi diri berpengaruh signifikan terhadap kemandirian belajar.

Berbagai penelitian dalam bidang akademik telah membahas mengenai efikasi diri. Beberapa peneliti telah melaporkan bahwa efikasi diri merupakan prediktor yang baik untuk menunjukkan ketertarikan dan prestasi siswa dalam pelajaran matematika. Siswa yang memiliki tingkat inteligensi yang baik, kepribadian, lingkungan sekolah yang mendukungnya, namun tanpa ditunjang dengan kemandirian belajar maka siswa tersebut tetap tidak akan mampu mencapai hasil belajar matematika yang optimal.

Berdasarkan hasil pengujian, dapat diketahui bahwa efikasi diri berpengaruh signifikan terhadap hasil belajar melalui kemandirian belajar.

Sejalan dengan hasil penelitian Ernawati (2013) bahwa efikasi diri merupakan komponen yang berperan dalam meningkatkan kemandirian belajar siswa yang pada akhirnya dapat meningkatkan hasil belajarnya. Salah satu karakteristik dari kemandirian belajar adalah siswa mempunyai kebebasan untuk memutuskan tujuan belajar apa yang hendak dicapai dan bermanfaat baginya. Bukan hanya efikasi yang berperan dalam kemandirian belajar namun ada beberapa faktor yang melatar belakanginya seperti, motivasi dalam belajar, mereka tidak memperoleh lingkungan kondusif untuk mengembangkan kemandiriannya. Hal in sejalan dengan pendapat Sardiman (2005: 73) motivasi adalah perubahan energi dalam diri seseorang yang ditandai munculnya feeling dan didahului dengan tanggapan terhadap adanya tujuan dan sesuai dengan pendapat Djamarah (2011) bahwa motivasi merupakan faktor utama yang menetukan keberhasilan belajar. Motivasi penting dalam menentukan seberapa banyak siswa akan belajar dari suatu kegiatan pembelajaran atau seberapa banyak siswa menyerap informasi yang disajikan kepada mereka.

Berdasarkan hasil pengujian, dapat diketahui bahwa kemandirian belajar berpengaruh tidak signifikan terhadap hasil belajar.
Hal ini sejalan dengan hasil penelitian yang dilakukan oleh Chanah (2011) yang mengemukakan bahwa tidak terdapat pengaruh yang signifikan antara kemandirian siswa terhadap prestasi belajar matematika. Selanjutnya hasil penelitian Suhendri (2013) tidak terdapat pengaruh yang positif kemandirian belajar terhadap hasil belajar matematika sejalan dengan itu Marcou A. dan George P. (2005) (Qohar, 2011: 119) menyatahan bahwa kemandirian belajar tidak bisa begitu saja ada pada siswa, tetapi guru harus memfasilitasi dan membuat lingkungan belajar yang mendukung agar kemandirian belajar bisa berkembang dengan baik. Selain itu siswa lebih senang berkumpul dan bekerja dalam kelompok. Siswa akan berhenti mengerjakan soal matematika yang diberikan ketika dirasa soal tidak dapat diselesaikan sendiri.

2. Aktivitas belajar berpengaruh positif terhadap hasil belajar matematika siswa baik secara langsung maupun tidak langsung (melalui kemandirian belajar).

Adapun faktor yang menyebabkan hal itu terjadi aktivitas-aktivitas belajar yang dilakukan oleh siswa tidak mendukung. Padahal aktivitas belajar siswa diperlukan dalam belajar karena pada prinsipnya belajar adalah berbuat untuk mengubah tingkah laku. Setiap orang yang belajar untuk aktif sendiri. Tanpa aktivitas maka proses belajar tidak mungkin terjadi. Oleh karena itu siswa akan lebih mudah memempelajari sesuatu dengan sendirinya. Sejalan dengan pendapat Hamalik (2001: 170), di dalam diri seseorang terdapat prinsip aktif, yaitu keinginan untuk berbuat dan bekerja sendiri. Prinsip aktif inilah yang mengendalikan perilaku siswa.

Selain aktivitas yang mempengaruhi hasil belajar ada beberapa faktor mempengaruhi hasil belajar, Seseorang yang belajar dengan semangat yang tinggi, maka akan menunjukan hasil yang baik, sebagaimana pendapat Sardiman (2005) yang menyatakan bahwa intensitas belajar siswa akan sangat menentukan tingkat pencapaian tujuan belajarnya yakni meningkatkan prestasinya. Perkataan intensitas sangat erat kaitannya dengan motivasi, antara keduanya tidak dapat dipisahkan sebab untuk terjadinya intensitas belajar atau semangat belajar harus didahului dengan adanya motivasi dari siswa itu sendiri. Sebagaimana Sardiman (2005) menyatakan bahwa belajar diperlukan 
adanya intensitas atau semangat yang tinggi terutama didasarkan adanya motivasi.

Kemandirian dalam mengerjakan tugas akan menumbuhkan sikap berusaha mengerjakan tugas sendiri tanpa harus tergantung pada orang lain dan siswa akan lebih tekun, ulet, serta akan memiliki rasa tanggung jawab dalam menyelesaikan tugasnya. Siswa yang memiliki tingkat kemandirian dalam mengerjakan tugas yang tinggi akan mengerjakan tugas-tugas sendiri tanpa mudah tergantung pada orang lain sehingga dapat mencapai prestasi belajar yang tinggi pula. Adanya aktivitas belajar dan kemandirian dalam mengerjakan tugas dalam proses belajar dapat mempengaruhi prestasi belajar. Siswa yang mempunyai kemandirian belajar yang tinggi terutama dalam mengerjakan tugas akan cenderung aktif dalam belajar. Sedangkan siswa yang kemandiriannya rendah biasanya kurang aktif dalam belajar.

3. Efikasi diri berpengaruh positif terhadap hasil belajar matematika siswa baik secara langsung maupun tidak langsung (melalui kemampuan berpikir logis).

Berdasarkan pengujian dapat diketahui bahwa efikasi diri berpengaruh signifikan terhadap hasil belajar melalui kemampuan berpikir logis.

Menurut Saragih (Kusumaningrum \& Aziz, 2012: 4), berpikir logis lebih mengacu pada pemahaman pengertian (dapat mengerti), kemampuan aplikasi, kemampuan analisis, kemampuan sintesis, bahkan kemampuan evaluasi untuk membentuk kecakapan. Efikasi diri yang tinggi dan kemampuan berpikir logis yang tinggi maka hasil belajar akan cenderung tinggi pula begitupun sebaliknya. Efikasi diri berperan dalam meningkatkan kemampuan berpikir siswa.

Selain itu faktor lain yang mempengaruhinya adalah kesiapan, menurut Jamies Drever (Slameto, 2010) kesiapan adalah untuk memberi respon atau reaksi. Kesiapan ini perlu diperhatikan dalam proses belajar mengajar, karena jika siswa belajar dan padanya sudah ada kesiapan, maka hasil belajarnya akan lebih baik. Selain itu pemahaman konsep juga dibutuhkan sebagaimana hasil penelitian Ferla, J. M. Valcke \& Y, Cai (2009) efikasi diri matematika dan konsep diri matematika memang mewakili secara konseptual dan empiris konstruksi yang berbeda, bahkan ketika belajar dalam domain yang sama, efikasi diri akademik adalah prediktor yang lebih baik (dan mediator) untuk prestasi akademik.

4. Aktivitas belajar berpengaruh positif terhadap hasil belajar matematika siswa baik secara langsung maupun tidak langsung (melalui kemampuan berpikir logis).

Terkait pengaruh langsung aktivitas belajar terhadap hasil belajar matematika Aktivitas pembelajaran dikelas, siswa bukan hanya diajarkan pada cara-cara berhitung namun siswa akan dihadapkan pada suatu permasalahan dalam pelajaran matematika yang berupa soal beraneka ragam yang harus dipecahkan oleh siswa sebagai hasil dari proses belajar matematika siswa tersebut. Dalam pemecahan masalah matematika dalam pembelajaran, hal yang sangat diperlukan adalah kemampuan berpikir logis yaitu kemampuan menemukan suatu kebenaran berdasarkan aturan, pola, atau logika tertentu. Sejalan dengan pendapat Kant (Tafsir, 2004: 35), berpikir logis adalah suatu pemikiran yang masuk akal yang kebenarannya mengandalkan argumen dan tidak diukur dengan hukum alam. Hal ini berarti dalam kata logis tersebut termuat suatu aturan tertentu yang harus dipenuhi sehingga membuahkan hasil yang benar. Orang berpikir logis akan taat pada aturan logika. Kemampuan berpikir logis diperlukan siswa, pada saat beraktivitas dalam mengambil keputusan, menarik kesimpulan, dan melakukan pemecahan masalah. Bentuk aktivitas yang dilakukan dapat berkaitan dengan masalah matematis maupun masalah yang ditemukan dalam kehidupan sehari-hari. Aktivitas lain yang dilakukan siswa dalam berpikir logis adalah ketika menjelaskan mengapa dan bagaimana suatu hasil diperoleh, bagaimana cara menarik kesimpulan dari premis yang tersedia, dan menarik kesimpulan berdasarkan aturan inferensi tertentu. Selain itu sesuai dengan hasil penelitian Nurfadillah Mahmud (2014), bahwa kecerdasan emosional berpengaruh positif terhadap prestasi belajar matematika siswa melalui kemampuan berpikir logis. Menurut Purwanto (2012) hasil belajar siswa akan meningkat apabila siswa mengembangkan kemampuan berpikir logis saat kegiatan pembelajaran berlangsung, hal ini bisa dilihat ketika siswa diberi permasalahan berupa soal-soal latihan maka siswa bisa menyelesaikannya dan siswa tidak terpaku pada satu persamaan yang ada. 


\section{SIMPULAN DAN SARAN}

Berdasarkan hasil analisis data penelitian pada bab sebelumnya, beberapa kesimpulan dari hasil penelitian ini adalah:

1. Sebagian besar siswa kelas VIII SMP Negeri Di Kecamatan Polongbangkeng Utara memiliki efikasi diri dalam belajar matematika dengan kategori tinggi, aktivitas belajar dalam belajar matematika dengan kategori tinggi, Kemandirian Belajar dalam belajar matematika dengan kategori tinggi, Kemampuan berpikir logis dalam matematika dengan kategori sedang dan hasil belajar matematika dengan kategori sedang.

2. Efikasi diri berpengaruh signifikan secara langsung terhadap hasil belajar dengan tingkat kepercayaan $93 \%$.

3. Efikasi diri berpengaruh tidak signifikan secara langsung terhadap aktivitas belajar dengan tingkat kepercayaan $48 \%$.

4. Efikasi diri berpengaruh signifikan secara langsung terhadap kemandirian belajar dengan tingkat kepercayaan $89 \%$.

5. Efikasi diri berpengaruh signifikan secara langsung terhadap kemampuan berpikir logis dengan tingkat kepercayaan $98 \%$.

6. Efikasi diri berpengaruh tidak signifikan secara tidak langsung terhadap hasil belajar melalui kemandirian belajar dengan tingkat kepercayaan $50 \%$.

7. Efikasi diri berpengaruh tidak signifikan secara tidak langsung terhadap hasil belajar melalui kemamuan berpikir logis dengan tingkat kepercayaan 52\%.

8. Aktivitas belajar berpengaruh tidak signifikan secara langsung terhadap hasil belajar dengan tingkat kepercayaan $26 \%$.

9. Aktivitas belajar berpengaruh signifikan secara langsung terhadap kemandirian belajar dengan tingkat kepercayaan $99 \%$.

10. Aktivitas belajar berpengaruh signifikan secara langsung terhadap kemampuan berpikir logis dengan tingkat kepercayaan $85 \%$.

11. Aktivitas belajar berpengaruh tidak signifikan secara tidak langsung terhadap hasil belajar melalui kemandirian belajar dengan tingkat kepercayaan $50 \%$.

12. Aktivitas belajar berpengaruh tidak signifikan secara tidak langsung terhadap hasil belajar melalui kemampuan berpikir logis dengan tingkat kepercayaan 52\%.

13. Kemandirian belajar berpengaruh tidak signifikan secara langsung terhadap hasil belajar dengan tingkat kepercayaan $22 \%$.

14. Kemampuan berpikir logis berpengaruh tidak signifikan secara langsung terhadap hasil belajar dengan tingkat kepercayaan $52 \%$.

Adapun saran dari penelitian ini yaitu; Kepada para guru yang bersangkutan sebaiknya memperhatikan faktor-faktor psikologis siswa diantaranya efikasi diri, aktivitas belajar, kemampuan berpikir logis, dan kemandirian belajar pada saat proses belajar dan mengajar matematika sehingga hasil belajar siswa meningkat.

Kepada peneliti yang berminat meneliti, agar meneliti sumbangan efektif efikasi diri, aktivitas belajar, kemampuan berpikir logis dan kemandirian belajar secara lebih mendalam serta variabel lain yang dapat memprediksi hasil belajar matematika siswa, misalnya: kurikulum, minat belajar, waktu belajar, dan kompetensi guru.

Kepada praktisi pendidikan, dalam menerapkan pengembangan aspek efikasi diri, aktivitas belajar, kemampuan berpikir logis dan kemandirian belajar pada siswa diharapkan melakukannya dalam bentuk pelatihan sehingga pengaruh yang didapatkan siswa lebih konkret. Selain itu memberdayakan guru-guru Bimbingan Konseling di masing-masing sekolah untuk menangani keempat variabel tersebut.

\section{DAFTAR RUJUKAN}

Arikunto S. 2006. Prosedur Penelitian Suatu Pendekatan Praktik. Jakarta: Rineka Cipta

Assagaf Gamar. 2014. Pengaruh Kemandirian Belajar dan regulasi diri terhadap hasil belajar matematika melalui motivasi berprestasi pada siswa kelas X SMA Negeri di kota Ambon. Tesis. Tidak diterbitkan. Makassar: Universitas Negeri Makassar (UNM).

Ernawati. 2013. Pengaruh Efikasi Diri, Konsep Diri, Aktivitas Belajar dan Kemandirian Belajar Terhadap Hasil Belajar Matematika Pada Siswa Kelas 
VII SMP Negeri Se-Kecamatan Somba Opu. Tesis. Tidak diterbitkan. Makassar: Universitas Negeri Malang (UNM)

Ghufron, M. N \& Risnawita, R. 2010. Teoriteori Psikologi. Jogyakarta: Ar-Ruzz Media Group.

Hidayah, D. R. 2011. Psikologi Kepribadian Dalam Konseling. Jakarta. Ghalia Indonesia.

Kusumaningrum \& Aziz. 2012. Mengoptimalkan Kemampuan Berpikir Matematika Melalui Pemecahan Masalah Matematika. Seminar Nasional Matematika dan Pendidikan Matematika. Yogyakarta: FMIPA UNJ.

Muslimin, T. P. 2014. Pengaruh Konsep diri dan minat belajar terhadap hasil belajar matematika melalui aktivitas dan kemampuan berfikir kreatif siswa kelas VIII SMP di Kecamatan Alla Kabupaten Enrekang. Tesis. Tidak diterbitkan. Makassar: Universitas Negeri Makassar (UNM)

Nurkancana \& Sunartana. 1992. Evaluasi Hasil Belajar. Surabaya: Usaha Nasional Nurhayati, Eti . 2011. Psikologi Pendidikan inovatif. Yogyakarta: Pustaka Pelajar
Ormrod, J. E. 2009. Psikologi Pendidikan Membantu Siswa Tumbuh dan Berkembang. Edisi Keenam. Jakarta. Erlangga

Slameto. 2010. Belajar dan Faktor-faktor yang Mempengaruhinya. Edisi Revisi. Cet: kelima. Jakarta: Rineka Cipta.

Tafsir, A. 2004. Filsafat Ilmu. Bandung: Remaja Rosda Karya

Tiro, M A, Suakrna, Aswi. 2010. Analisis Jalur. Makassar: Andira Publisher.

Wahyuddin. 2013. Pengaruh Kemampuan Berpikir Logis Dan Kemampuan Verbal Menyelesaikan Soal Cerita Matematika Melalui Kemampuan Penalaran Dan Komunikasi Pada Siswa Kelas Vii Smp Muhammadiyah Se Kota Makassar. Tesis. Makassar: Universitas Negeri Makassar (UNM).

Wahyuni, D .S. 2014. Pengaruh Efikasi Diri, Cara Belajar, Persepsi Siswa tentang Komunikasi Guru dan Persepsi Siswa tentang Perhatian OrangTua Terhadap Hasil Belajar Matematika Siswa Kelas XI MAN Di Kota Palu. Tesis. Tidak diterbitkan. Makassar: Universitas Negeri Makassar (UNM). 